\title{
A Review of the Restorative Environment Research in the Mainland of China
}

\author{
Meng Ruoxi ${ }^{*}$, Xu Leiqing ${ }^{2}$ \\ ${ }^{1}$ Master Student,College of Architecture and Urban Planning, Tongji University, Shanghai,200092,P.R.China \\ ${ }^{2}$ Professor, College of Architecture and Urban Planning, Tongji University, Shanghai,200092,P.R.China
}

\begin{abstract}
More and more Chinese experts focus on the research field of the restorative environment and public health. We reorganized the theories of restorative environment and proposed a theory framework which consists of Attention Restorative Theory(ART) and psycho-evolutionary theory and other three auxiliary hypothesis included Biophilia Theory, Prospect-Refuge Theory and Stress: The "fight or flight" response We classified the experiments methods into three types; the psychological, subjective evaluation, physiological objective indicators, and behavior improvements . We could figure out some shared questions at the current research in mainland China, such as limited research methods, limited senses used in the current research.
\end{abstract}

(c) 2016. The Authors. Published for AMER ABRA by e-International Publishing House, Ltd., UK. This is an open access article under the CC BY-NC-ND license (http://creativecommons.org/licenses/by-nc-nd/4.0/).

Peer-review under responsibility of AMER (Association of Malaysian Environment-Behaviour Researchers), ABRA (Association of Behavioural Researchers on Asians) and CE-Bs (Centre for Environment-Behaviour Studies), Faculty of Architecture, Planning \& Surveying, Universiti Teknologi MARA, Malaysia.

Keywords : Restorative; Theory;Questionnaire;Experiments

\section{Introduction}

With the accelerated process of urbanization and the arrival of the information age, the pace of people's work is more and more intense, the working time is longer and longer, and pressure people feel in their work gradually increased. An increasing number of work occupies more and more leisure time. The study showed that people under pressure for a long time are more likely to exhibit impatience, anxiety, depression and other negative emotions. According to the World Health Organization, mental health and cardiovascular diseases have become the two biggest killers of human well-being (WHO, 2008).Long-term pressure including cardiovascular will generate serious damage to the internal organs of the body, and it will bring depression related psychological problems.

\footnotetext{
${ }^{*}$ Corresponding author. Tel.: +86-181-0187-0131

E-mail address:272443564@qq.com
}

2398-4287 @ 2016. The Authors. Published for AMER ABRA by e-International Publishing House, Ltd., UK. This is an open access article under the CC BY-NC-ND license (http://creativecommons.org/licenses/by-nc-nd/4.0/).

Peer-review under responsibility of AMER (Association of Malaysian Environment-Behaviour Researchers), ABRA (Association of Behavioural Researchers on Asians) and cE-Bs (Centre for Environment-Behaviour Studies), Faculty of Architecture, Planning \& Surveying, Universiti Teknologi MARA, Malaysia.

DOI: http://dx.doi.org/10.21834/e-bpj.v1i3.358 
In recent years, experts have found that in experiments some environments can help people reduce stress and a variety of negative emotions, and promote people's mental and physical health. This is called "restorative environment", which is defined as the environment that can help people reduce stress and reduce mental fatigue and promote mental and physical health. Natural surroundings allaying impatience, depression, and another negative psychological state has a definite influence to enhance physical health of people. The modern buildings and busy work just like cages that create barriers between man and nature, and prevent the people close to nature, enjoy life and relax. How to solve this problem? Urban planners, architects and landscape designers come up with an idea by implanting artificial natural environment in the city, such as parks, small public green space, roof garden, vertical greening, so that it can increase the chance of contacting with nature for people in their daily life. In a highdensity urban environment with so many skyscrapers, large public green seems too extravagant for the user and is not realistic. High-density urban areas is often a gathering place for a large building complex with hotels, offices, commercial, etc. There is a large population of a big portion of working people. How to effectively implant natural landscape in a high-density area, and create a comfortable and pleasant environment with restorative function, have become contemporary problems to be solved.

\section{The development of the theory of restorative environment}

In 1983, Kaplan and Talbot, two researchers from the University of Michigan, studied the impact of two-week wildlife on people's psychology, found that wildlife for most people had restorative function, and they first proposed the concept of "restorative environment" and defined it to be able to help people reduce stress and accompanying negative emotions and then reduce mental fatigue. As a result, it could promote mental and physical health because of the environment. In 2001, Hartig had proposed been a further explanation, added that "recovery" meant regain the physical, psychological and social competence which were lost in the process of adapt to the external environment.

\subsection{Attention Restorative Theory, ART}

Rachel \& Stephen Kaplan divided attention into involuntary care and voluntary attention. Involuntary attention means that people do not need to spend too much attention, they will quickly be attracted by things. Voluntary attention, known as direct care, suggests a kind of capability that purposeful activities prohibit or block distractions source or related stimuli. Kaplan's' noted this autonomous capability as a resource when people use their direct attention firmly and persistently, it will result in the loss of such support, namely mental fatigue. Individuals will make mistakes, behave impulsively or easily be frequently irritated. However, in the restorative environment, the ability will effectively recover, and the person will experience deep physical and psychological repair and restore the direct attention of resources. What's more, it will enhance the ability to reflect on the critical errors. Restorative environment should have the following four characteristics:

\section{(1) Being away}

Helping people escape from a state of fatigue or stress. Being away can be, for example, deep into the forest and breathe fresh air, or be out of the window and then overlook or admire a painting visually, or psychologically, such as imagining you want to live in a particular place.

(2) Fascination

The environment is attractive enough to be able to grab people's attention. Attraction is not only from the interesting things or places, but also from the process, such as thinking, working, and curious. Nature is well endowed with attraction - plants, animals, water and light. It also has a tendency to be naturally attracted.

(3) Extent

Space with rich enough content to make people feel that they are moving away from the pressure, living in an entirely different world. This place needs to not only be large enough or have enough content to lead people to explore but be able to attract people's attention as well.

\section{(4) Compatibility}


The environment has a good match with people's requirements and personal purposes, or the environment encourages activities. For example, people in a quiet place desire to stay alone, so they find to hide in a corner of the garden benches. An incompatible example might be a person, who is eager to go outside for a walk, unfortunately, catch in inclement weather, or is locked in the room.

\subsection{Decompression theory}

Decompression theory was put forward by Roger Ulrich, which is also known as the psychological theory of evolution. Ulrich believes that urban construction, transportation, and environmental stimuli are complex. The crowd, noise, rubbish and other environmental issues seriously tormented the life of urban residents. Urban dwellers often appear anxiety and their autonomic arousal level remained high, and also at a higher pressure level. Ulrich pointed out that when an individual was under pressure or stress, exposure to the certain natural environment could reduce the damage of physiology, psychology and behavior caused by the stressors from the human environment.Urban environment often has hindered this mitigation process. Since natural scenery attracts person's attention and causes positive emotions, it can bring relieve stress effect as the result. By empirical research on restorative environment, Ulrich put forward that restorative environment should meet the following requirements: a proper depth and complexity of the overall structure and particular singular focus, containing enough plant, water, and other natural elements, and there is no danger. Only in this way will it be possible to set an environment with real restorative ability.

Attention restoration theory and decompression theory are the two theoretical bases for current restorative environment studies and have made great contributions to explaining the substantial impact on human mind from the natural environment. Also, researchers in the restorative environment also refer to the following three theories:

\subsection{Biophilia Theory}

The method is proposed by Erich Fromm, a social psychologist, according to the term --biophilia, which is defined that life is full of passion and love, everything is full of life, and everyone loves human and nature. The word comes from the Latin word bio which means life and philia which means attraction. In "The Biophilia Hypothesis" this book, the author Wilson believes that "if possible, biophilia exist in the world. Compared to other organisms, this property is essential emotion accessories of human and means genetic, so this will eventually become a part of human nature. "

\subsection{Prospect-Refuge Theory}

This environmental, aesthetic theory was put forward by the geographer Jay Appleton, emphasizing the critical role of human's self-preservation instinct in the landscape evaluation process. Human needs landscape to provide "shelter" in a particular place, and this housing can provide with better view sight so that he can observe the surroundings.

\subsection{Stress: The "fight or flight" response}

This was proposed by Walter Cannon, referring that the change of body within two seconds after people experience stress. At This stage, the so-called panic stage, the body releases adrenaline into the bloodstream. Epinephrine brings a powerful force to the body and produces many other changes in the organ, so that people can prepare for these changes and take quick action.

We organized the literature on restorative environmental studies in recent years and summarized above five theories, which constitute the basic theoretical framework of restorative environmental studies, in which attention restoration theory (ART) and decompression theory (evolutionary psychology academic) are the most convincing and a complete theory. All kinds of scholars have widely used These two theories. And the other three, Biophilia Theory, Prospect-Refuge Theory and Stress: The "fight or flight" responses as an auxiliary further explain that 
human nature is innate preferences, and is a property of humanity. They support the restoration of the natural environment and the importance and legitimacy of the research to some extent. Domestic theoretical research on restorative environment also relies on the conceptual framework.

\section{Methods}

For research purposes, at home and abroad, it's mainly from three aspects, subjective assessment of psychological, physiological objective indicators and improved behavior. Researchers collect data of either one of these three elements to assess and measure the restorative effect of particular environment. For subjective psychological assessment, it is mainly conducted through a questionnaire survey, then analysis the data and comparison. When using objective indicators of physiological or behavioral improvement for the study, the relevant data come from comparing experiment. Methods test restorative effect of the environment on tested from qualitative and quantitative these two aspects.

\subsection{Questionnaire}

This approach is mainly relying on Perceived Restorative Scale healing made by Hartig, Korpela, and Evans in 1996, which is the first questionnaire for restorative environmental. Until now, it has been widely used in this field. According to the four features of restorative environment, being away, fascination, extent,compatibility, from attention restorative theory, researchers has raised some questions related to restorative environment. They ask the tester score each question of PRS, using 0 to 6 , according to their situation. The score of PRS is higher, the effect of restorative environment is better. In 1997, Hartig, Kaiser, and Bowler added ten items by 16 questions of the original one, bringing the total questions up to 26. In 2001, Laumann, Garling, and Stormark divided dimension "away" into "new" and "Escape", two dimensions.So the size of PRS scale is increased from four to five, the total number of items becomes 22. In 2003, Herzog and Maguire Nebel simplified the original PRS, re-introduced the "left", and defined it as the "escape" with the similar meaning, and the definition of "compatibility" was focused on whether the environment is so comfortable or not. The environment has become an object of analysis. There are scholars also have been involved in completing the PRS. In 2003, Han, from Taiwan, made the Self-Rating Restoration Scale, SRRS, by decompression theory and attention restorative theory. The scale covers the emotions, physical, cognitive and behavior, this four dimensions, including eight topics. Through continuous development, the PRS, proposed by Hartig in 1997 is still the most widely used one all over the world, including 23 projects with four dimensions.

Some questionnaire will adopt another psychological scales - Profile of Mood State, POMS, emotional sectional questionnaire, which consist of 40 adjectives, including tension, anger, fatigue, depression, energy, panic and selfesteem these seven emotional subscales that are used five scale method to answer questions, the corresponding score from 0 to 4 points with the meaning of little to very. The score of POMS is higher; the mental health is worse. The difference of POMS index between different populations indicates significant differences in their mental health status. In 2008, Guo Erlang and his colleague from the City Room of Beijing Forestry University studied the relationship between the using frequency of urban green space and urban residents mental health in Beijing, Chengdu, Guangzhou,Hefei these four cities. They use the POMS ask urban dwellers with questions such as how long and when they will visit the urban green space.

\subsection{Experiment}

The experimental procedure is divided into the following three steps. Firstly, the subjects are asked to complete a series of tests, writing papers or to watch some of the unpleasant image data, etc., to make items into the fatigue state and to introduce pressure. Some scholars directly select a subject who is already in a state of stress or fatigue to carry out comparative studies, such as selecting those who fail the school examination or are required to participate in the rebuilding review. Then, let the subjects experience in different simulated or real environment for a period which is usually playing color photos and slides of the different environment on the screen; or make subjects 
watching environmentally related videos, to allow participants to restore energy and to release the pressure. Last but not least, using different methods of professional analysis by the feature of the data collected (behavioral improving or physiological indicators), to compare the difference of the effects of the different environmental recovery.

In the experiments using physiological indicators as experimental objects, subjects are asked to watch for particular types of environmental image (such as forests, grasslands, deserts, town, commercial, etc.), and their physiological changes are continuously measured----alpha wave amplitude, blood pressure, ECG, transcutaneous electrical, EMG, pulse and muscle tension. Some scholars use a more detailed quantification of medical testing equipment, such as facial muscles tester(muscle per unit, cheekbones muscles, etc.) and EOG test instrument, to get quantitative data. But the disadvantage of this experiment is the duration of time is long, which can easily make the subjects feel tired.

In the experiments using behavioral improving as measurement experiment objects, the evaluation of environmental restorative effect comes out of the behavioral changes of the items which are under the circumstances before and after introducing into the pressure or before and after the changes of the environment they face.

\section{Outstanding research scholars in China}

Currently, there are not many scholars specializing in restorative environment and the related works and literature are limited. From the existing data, students are roughly grouped into two types. One is based on psychology research, primarily studying the different effects of the different environment to the psychology and physiology of people from the micro-level, such as Su Qian from Beijing Normal University, Xin ZiQiang, and other scholars. The other is based on the design research, primarily studying the relationship between the environment and public health in macro levels, such as Professor Tan Shaohua from Chongqing University, who has been, in recent years, committed to the relationship between public open space, such as green areas, and the pressure relax, fatigue relieve of city resident.

\section{Existing problems}

By sorting the research literature on restorative environment in mainland China, we find the following questions.

4.1 because restorative environment studies in the continent China just started, there are not many scholars and experts in this field; the existing literature related to the research methods are mostly borrowed from abroad; more traditional experimental ideas are still used; most comparative experiments are simple and lack of innovation. The experts and scholars of Europe have used more advanced scientific instruments such as experimental data collection and have been making a change in this base.

4.2 Current domestic researches mainly focus on the restoration effects differences between the natural environment and the urban environment and repeatedly verify that the former is better. Combining with the characteristics of modern life, urban environment or artificial environment has a closer relationship with the people. It is no exaggeration to say that all the time people live in the particular urban environments. So, we can shift the focus of research to the urban environment or the existing artificial environment and restorative environment. We can rationally put restorative environment into architecture design, town planning or landscape design.

4.3 The environments used in the current study are mostly simulation environments, which are created by twodimensional images such as pictures or videos. However, the real situation is a multidimensional, comprehensive result to the physiology and psychology of people by the collaborative working of five senses, maybe more, of watching, listening, smelling, touching and tasting. Relying solely on the two-dimensional image of the simulated environment cannot be objective and comprehensive to the pros and cons of the environment effects to people. 


\section{Prospect}

Due to the fast-paced working life, more and more pressure are brought to people, negative emotions in life increase, and environmental impacts on people's physical and mental are gradually highlighted. To timely introduce the concept of restorative environmental into the field of design and get rid of the traditional methods of restorative environmental analysis, we can combine urban planning, architecture, and landscape design to create more charming spaces which can promote public health and are full of vigorous and dynamic vitality.

\section{References}

房城, 郭二果, 王成, 郄光发, 孙志伟, 李春媛. 城市绿地的使用频率与城市居民心理健康的矢系[]]. 城市环境与城市生 态,2008,02:10-12.

昆军,刘德明.走向生态自然观的医院建筑康复环境[]]. 华中建筑,2008,05:80-83.

昆军,刘德明. 趋近自然的医院建筑康复环境设计[J]. 建筑学报,2008,05:83-85.

谭少华,段炼,赵万民,宋晓霞.基于能值分析的人居环境建设系统价值评价[J].城市规划学刊,2009,03:53-57.

谭少华,李进.城市公共绿地的压力释放与精力恢复功能[J].中国园林,

2009,06:79-82.

谭少华,郭剑锋,赵万民.城市自然环境缓解精神压力和疲劳恢复研究进展[J].地域研究与开发,2010,04:55-60.

苏谦,辛自强.恢复性环境研究:理论、方法与进展[J].心理科学进展,

2010,01:177-184.

赵欢,吴建平.复愈性环境的理论与评估研究[J].中国健康心理学杂志, 2010,01:117-121.

叶柳红,张帆,吴建平.复愈性环境量表的编制[J].中国健康心理学杂志, 2010,12:1515-1518.

苏谦,池丽萍.环境的恢复性功能:测量及应用[J]. 社会心理科学,2012,02:89-95.

吴正旺,马欣,杨金高.高密度城市居住区的“绿视率”调查一以北京为例[]].华中建筑,2014,02:85-89.

谭少华,雷京.促进人群健康的社区环境与规划策略研究[J].建筑与文化,

2015,01:136-138.

谭少华,洪颖.居住绿地的使用与城市居民健康的䏌系研究[J].建筑与文化,

2015,02:108-109.

姜斌,张恬,威廉.C.苏利文.健康城市:论城市绿色景观对大众健康的影响机制及重要研究问题[J].景观设计学,2015,01:24-35.

张俊彦,唐宜君. 健康的城市生态与健康的人[J]. 景观设计学,2015,01:45-53.

乔·克兰西,雷康铃.亲自然的景观设计对改善健康与福祉的作用[J].景观设计学,2015,01:54-61.

克里斯托弗·韦伯斯特,钱莫伊·沙卡, 斯考特·杰宁斯·墨尔本, 彭文辉, 邓信惠, 内扎尔·卡法菲. 绿色等于健康? 建立高密度健康城 市研究的实证基础[J]. 景观设计学, 2015,01:8-23

徐菪青, 杨公侠.环境心理学[M]

Clare Cooper Marcus. Therapeutic Landscapes: An Evidence-Based Approach to Designing Healing Gardens and Restorative Outdoor Spaces[M]. Wiley:Wiley, 2013.

Jenny Roe. The Restorative Power of Natural and Built Environments[M]. Heriot-Watt University:Heriot-Watt University, 2008. 
Korpela, K. M., Hartig, T., Kaiser, F. G., \& Fuhrer, U. Restorative experience and self-regulation in favorite places[J]. Environment and Behavior, 2001.

Korpela, K., \& Hartig, T. Restorative qualities of favorite places[J]. Journal of Environmental Psychology, 1996.

Tseng, A. T.. The relationship between landscape environment and well-being and restoration. Paper presented at the International People-Plant Symposium IPPS, Awaji Shima, Japan,2004.

Ulrich, R. S., Simons, R. F., Losito, B. D., Fiorito, E., Miles, M. A., \& Zelson, M..Stress recovery during exposure to natural and urban environments. Journal of Environmental Psychology, 1991.

Ulrich R. View Through A Window May Influence Recovery From Surgery[ J] .Science,1984. 